\title{
RANCANG BANGUN SISTEM INFORMASI AKADEMIK (STUDI KASUS : SMPIT NURUL ISLAM TENGARAN)
}

\author{
Julian Chandra Wibawa \\ Program Studi Sistem Informasi \\ Universitas Komputer Indonesia \\ maeztro_87@yahoo.co.id
}

\begin{abstract}
ABSTRAK
Saat ini penerapan teknologi informasi banyak dimanfaatkan dalam berbagai bidang, tidak terkecuali pada bidang pendidikan. Pada sebuah instansi pendidikan tentunya sangat membutuhkan sistem informasi dalam mengatur kegiatan akademik yang cepat, efektif, efisien, akurat untuk meningkatkan standar mutu pendidikan pada instansi pendidikan tersebut. Kegiatan akademik, terutama pada kegiatan pendaftaran dan pengolahan nilai rapor hafalan siswa di SMPIT Nurul Islam Tengaran perlu didukung oleh sistem infomasi berbasis teknologi informasi yang dapat memudahkan kegiatan tersebut. Permasalahan yang terjadi saat ini antara lain kegiatan pendaftaran yang masih dilakukan secara manual dan juga pembuatan rapor yang berisikan nilai hafalan dan rekap absen pun masih dilakukan secara manual. Penelitian diawali dengan studi literatur, pengumpulan data, perancangan, pengujian, dan penyajian perangkat lunak. Dengan adanya SIAK (Sistem Informasi Akademik) dapat membantu kegiatan pendaftaran dan pembuatan rapor menjadi lebih mudah, meminimalisir resiko terjadinya kesalahan dan membuat semua proses menjadi lebih cepat.
\end{abstract}

Kata Kunci : Sistem Informasi, Akademik, Pendaftaran, Nilai Harian, Absensi, Rapor.

\section{PENDAHULUAN}

Pesatnya perkembangan teknologi dewasa ini seolah tidak mengenal ruang dan waktu, menuntut kita semua untuk terus mengikuti arus perkembangan teknoloogi, terutama di era globalisasi saat ini. Dalam pengelolaan informasi, diperlukan teknologi yang dapat mempermudah pekerjaan sehingga dengan informasi tersebut dapat mempermudah pekerjaan maksimal.

Pemakaian teknologi informasi dalam segala bidang selain untuk memberikan kemudahan, juga dapat mengerjakan pekerjaan dengan cepat, tepat dan akurat. Dewasa ini penggunaan teknologi informasi menjadi syarat utama untuk menunjukkan kualitas dan menjadi modal terpenting dalam memenangkan persaingan.

Untuk sebuah instansi pendidikan tentunya sangat membutuhkan sistem informasi dalam mengatur kegiatan akademik yang cepat, efektif, efisien dan akurat untuk meningkatkan standar mutu pendidikan pada instansi pendidikan tersebut.

Sejalan dengan visi, misi dan budaya institusi, serta untuk meningkatkan standar mutu pendidikan SMPIT Nurul Islam
Tengaran sangat membutuhkan sistem informasi yang dapat memudahkan kegiatan akademik, terutama pada kegiatan pendaftaran penerimaan peserta didik baru (PPDB) dan penilaian rapor hafalan siswa.

Pendaftaran PPDB SMPIT Nurul Islam Tengaran merupakan kegiatan penyaringan pendaftar yang dilaksanakan setahun sekali. Kegiatan ini cukup menyita waktu dan tenaga para peserta dan panitia karena masih dilakukan secara manual. Sedangkan peserta yang mendaftar cukup banyak dan bukan hanya dari kota Semarang saja, bahkan ada yang dari luar propinsi.

Berikut di bawah ini tabel 1 yang berisikan data penerimaan peserta didik baru SMPIT Nurul Islam tahun ajaran 2017/2018.

Tabel 1 : Data peserta penerimaan peserta didik baru tahun ajaran 2017/2018

\begin{tabular}{c|cc}
\hline \hline Keterangan & Laki-laki & Perempuan \\
\hline Pendaftar & 161 orang & 151 orang \\
\hline Diterima & 120 orang & 100 orang \\
\hline
\end{tabular}

Sumber : Panitia penerimaan peserta didik baru tahun ajaran 2017/2018 
Berikut data kota asal pendaftar dapat dilihat pada tabel 2 di bawah ini

Tabel 2 : Data kota asal peserta PPDB tahun ajaran 2017/2018

\begin{tabular}{|c|c|c|}
\hline Provinsi & Pendaftar & Diterima \\
\hline Jawa Tengah & 290 orang & 207 orang \\
\hline DKI Jakarta & 4 orang & 4 orang \\
\hline Kep. Riau & 3 orang & 3 orang \\
\hline KalTeng & 3 orang & 3 orang \\
\hline Lainnya & 12 orang & 3 orang \\
\hline
\end{tabular}

Sumber : Panitia penerimaan peserta didik baru tahun ajaran 2017/2018

Terdapat beberapa masalah yang sering muncul dalam kegiatan penerimaan PPDB yang dilakukan secara manual. Masalah pertama dan utama yaitu diperlukan waktu yang lama untuk peserta datang langsung ke SMPIT Nurul Islam Tengaran guna mengisi formulir pendaftaran dan membawa berkas lampiran yang dibutuhkan. Untuk proses verifikasi berkas para peserta harus menunggu hingga mendapat giliran verifikasi data oleh panitia. Masalah selanjutnya yaitu bisa terjadinya kesalahan saat pembuatan surat keputusan yang berisikan biaya daftar ulang yang berbeda untuk tiap siswa yang diterima. Untuk rekap absen dan nilai hafalan harian, para penanggungjawab (muhafiz) harus menulis ulang dan menghitung jumlah kehadiran tiap siswa yang dibimbingnya.

Berdasarkan latar belakang tersebut, maka dirancang sebuah sistem informasi akademik (SIAK) pada kegiatan pendaftaran dan pembuatan rapor di SMPIT Nurul Islam Tengaran.

\subsection{Identifikasi Masalah}

Untuk membuat sebuah sistem informasi akademik pada dasarnya dibutuhkan beberapa variabel penting yang mendukung seperti data pendaftar, data hasil penyaringan, data siswa, data muhafiz, data nilai dan data rapor.

Berdasarkan uraian sebelumnya, ditemukan masalah yang terjadi di tempat melaksanakan penelitian. Adapun permasalahan yang diidentifikasi adalah:

1. Pelaksanaan pendaftaran masih dilakukan secara manual yaitu dengan mengisi formulir pendaftaran dan menyertakan berkas pendukung.
2. Hasil penyaringan berupa surat keputusan masih dibuat manual menggunakan Microsoft Word. Dengan mengganti nama pendaftar, hasil keputusan dan biaya daftar ulang untuk setiap pendaftar.

3. Absensi siswa masih manual tercatat di buku absen yang direkap tiap semester untuk dicatat di buku rapor.

4. Untuk siswa yang berpindah kelompok hafalan, data tertulis nilai hafalan dari kelompok sebelumnya harus diberikan kepada muhafiz di kelompok baru untuk nantinya dimasukkan ke rapor.

5. Rekap nilai siswa tercatat di buku nilai hafalan yang nantinya ditulis ulang saat pembuatan rapor.

\subsection{Rumusan Masalah}

Mengingat begitu luasnya permasalahan yang ada serta untuk menghindari penafsiran yang terlalu jauh pada uraian, maka dirumuskanlah masalah yang ada sebagai berikut :

1. Bagaimana berjalannya proses sistem pendaftaran siswa baru di SMPIT Nurul Islam.

2. Bagaimana berjalannya sistem penilaian dan absensi siswa hingga pembuatan rapor di SMPIT Nurul Islam.

3. Bagaimana membuat dan merancang sebuah perangkat lunak yang mampu membuat proses pendaftaran dan penilaian pada SMPIT Nurul Islam.

\subsection{Batasan Masalah}

Perlunya dibuat batasan masalah yaitu untuk membatasi sejauh mana perancangan yang diusulkan agar terselesaikannya masalah yang didapatkan tanpa menambah masalah baru. Batasan masalah tersebut terdiri dari :

1. Sistem yang dirancang hanya merubah teknis pengisian formulir pendaftaran dari penulisan di kertas menjadi pengisian form secara online.

2. Sistem yang dirancang berdiri sendiri. Tidak berhubungan dengan database yang sudah ada. Data muhafiz diinput ke dalam sistem yang telah dirancang.

3. Terdapat fasilitas export data untuk menginput datapendaftar yang lolos dengan extention .xls 
4. Pendaftar hanya dapat melihat hasil penyaringannya dan surat keterangan milik sendiri.

5. Adanya fasilitas untuk mengubah data siswa, data muhafiz, absen, nilai dan rapor.

6. Pada sistem informasi ini formulir pendaftaran, kartu ujian, surat keterangan hasil penyaringan serta rapor yang berisikan nilai hafiz dan rekap absen siswa dapat di export dalam format pdf

7. Untuk data peserta lolos ujian beserta biaya daftar ulangnya, data siswa, dan data muhafiz dapat di export dalam format excel.

\section{TINJAUAN PUSTAKA}

\subsection{Pengertian Sistem}

Menurut Azhar Susanto dalam bukunya yang berjudul Sistem Informasi Akuntansi: Sistem adalah kumpulan/group dari sub sistem/bagian/komponen apapun baik phisik ataupun non phisik yang saling berhubungan satu sama lain dan bekerja sama secara harmonis untuk mencapai satu tujuan tertentu. [1]

Sementara Mohamad Subhan dalam bukunya yang berjudul Analisa Perancangan Sistem mendefinisikan pengertian dari sistem sebagai berikut: Suatu sistem dapat diartikan sebagai suatu kumpulan atau himpunan dari unsur, komponen, atau variable-variabel yang terorganisasi, saling berinteraksi, saling tergantung satu sama lain dan terpadu. Sistem juga merupakan kumpulan elemen-elemen saling terkait dan bekerja sama untuk memproses masukan (input) yang ditujukan kepada system tersebut dan mengolah masukan tersebut sampai menghasilkan keluaran (output) yang diinginkan. [2]

Berdasarkan beberapa pendapat yang dikemukakan di atas dapat ditarik kesimpulan bahwa sistem adalah kumpulan bagian-bagian atau sub sistem-sub sistem yang disatukan dan dirancang untuk mencapai suatu tujuan.

\subsection{Pengertian Informasi}

Rudy Tantra dalam bukunya Manajemen Proyek Sistem Informasi juga mengungkapkan tentang pengertian informasi yaitu: Informasi dapat dipahami sebagai pemrosesan input yang terorganisir, memiliki arti, dan berguna bagi orang yang menerimanya. Data berbeda dengan informasi. Data dapat didefinisikan sebagai fakta-fakta yang masih mentah atau acak yang menjadi input untuk proses yang menghasilkan informasi. [3]

\subsection{Sistem Informasi}

Abdul Kadir memberikan penjelasan bahwa sistem informasi adalah sebuah rangkaian prosedur formal dimana data dikelompokkan, diproses menjadi informasi, dan didistribusikan kepada pemakai. [4]

Pengertian lain dari Rudy Tantra bahwa sistem informasi adalah sebagai berikut: Sistem informasi adalah cara yang terorganisir untuk mengumpulkan, memasukan, dan memproses data dan menyimpannya, mengelola, mengontrol dan melaporkannya sehingga dapat mendukung perusahaan atau organisasi untuk mencapai suatu tujuan. [3]

\subsection{Pengertian Akademik}

Akademik atau akademis menurut Kamus Besar Bahasa Indonesia berarti bersifat ilmiah; bersifat ilmu pengetahuan; bersifat teori, tanpa arti praktis yang langsung. [5]

\subsection{Pengertian Pendaftaran}

Pengertian pendaftaran menurut Kamus Besar Bahasa Indonesia adalah : proses, cara, perbuatan mendaftar (mendaftarkan); pencatatan nama, alamat, dan sebagainya dalam daftar; [5]

\subsection{Pengertian Rapor}

Kata rapor menurut Kamus Besar Bahasa Indonesia yaitu : laporan resmi (kepada yang wajib menerimanya). [5]

\subsection{Aplikasi Web}

Menurut Sutabri, aplikasi adalah alat terapan yang difungsikan secara khusus dan terpadu sesuai kemampuan yang dimilikinya [6]

Menurut Asropudin dalam bukunya menjelaskan bahwa web adalah sebuah kumpulan halaman yang diawali dengan halaman muka yang berisikan informasi, iklan, serta program aplikasi. [7]

Aplikasi berbasis web berjalan pada suatu jaringan internet sehingga dapat diakses dimana saja. Aplikasi web paling dasar ditulis 
dengan menggunakan HTML (HyperText Markup Language). Pada perkembangannya, beberapa script lain dikembangkan untuk memperluas kemampuan HTML, antara lain PHP, ASP, ASP.NET, dan lain-lain

\subsection{PHP}

PHP (singkatan rekursif PHP : Hypertext Preprocessor) adalah bahasa scripting yang bersifat open source yang banyak digunakan untuk pengembangan web dan dapat ditanamkan ke dalam HTML (php.net). PHP dapat diintegrasikan dengan MySQL sehingga memungkinkan membuat suatu aplikasi yang dapat mengelola dan memanipulasi data. PHP merupakan bahasa pemrograman yang bersifat server side scripting, dimana PHP bekerja pada sisi server. [8]

\subsection{MySQL}

MySQL merupakan sebuah program aplikasi untuk membuat database yang umum digunakan pada web server. MySQL banyak digunakan karena kemampuannya dalam menampung data yang cukup besar dan proses loading yang cepat dalam pemanggilan data. Database MySQL merupakan sebuah fasilitas untuk menyimpan database dan dapat memprmudah user dalam membuat form password, log in, guest book, contact, dan lainlain. [8]

\subsection{Metode Penelitian}

\subsubsection{Metodologi Penelitian}

Metodologi penelitian yang akan digunakan dalam menyelesaikan penelitian ini secara umum dapat dilihat pada Gambar 1 berikut [8]:

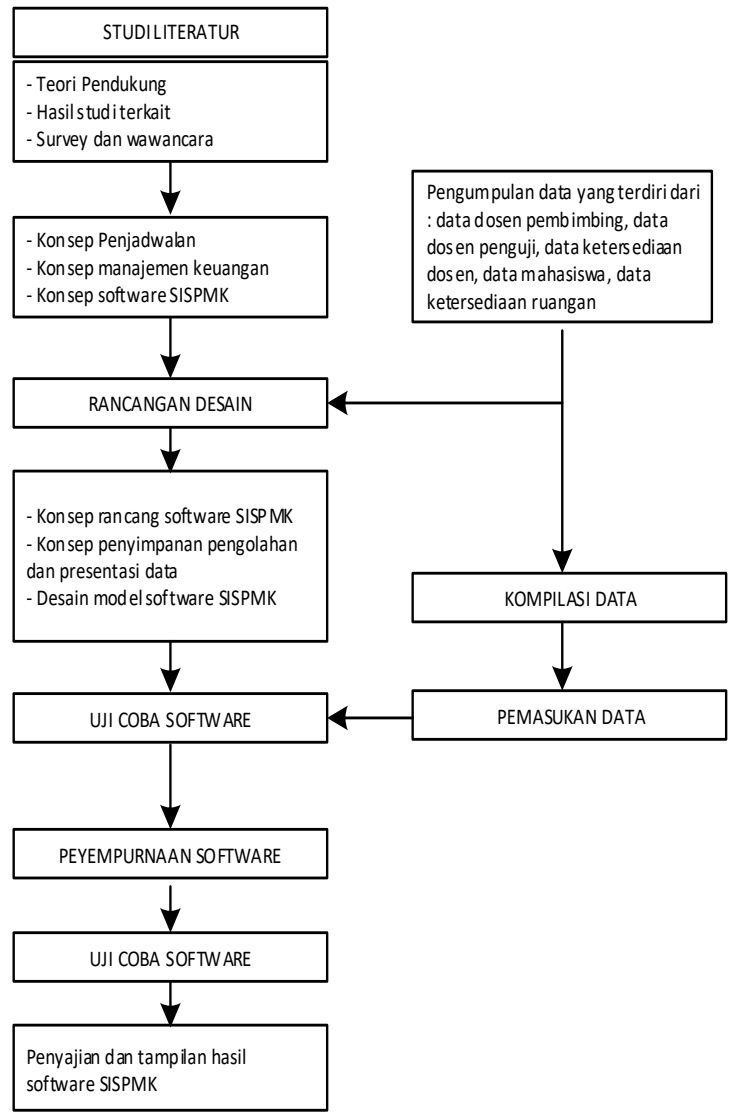

Gambar 1. Metodologi penelitian

1. Studi literatur

2. Metode pengumpulan data

3. Rancangan desain

4. Penggunaan algoritma penjadwalan

5. Uji coba software

\subsubsection{Metode Pendekatan Sistem}

Metode Pendekatan sistem yang digunakan pada penelitian ini menggunakan metode terstuktur yaitu suatu proses untuk mengimplementasikan urutan langkah untuk menyelesaikan suatu masalah dalam bentuk program.

\subsubsection{Metode Pengembangan Sistem}

Penggunaan metode pengembangan sistem dengan model prototype digunakan dalam perancangan sistem informasi ini dikarenakan pada metode ini pengembang dan User dapat saling berinteraksi selama proses pembuatan sistem. Tahapan-tahapan dalam Prototyping adalah sebagai berikut [8] :

1. Mengidentifikasi kebutuhan : analisa terhadap kebutuhan calon user.

2. Quick design : pembuatan desain secara global untuk membentuk 
perangkat lunak atau software sebagai contoh.

3. Build prototype : pembuatan perangkat lunak prototipe termasuk pengujian dan penyempurnaan.

4. Evaluasi pelanggan: mengevaluasi prototipe dan memperhalus analisa kebutuhan calon pemakai.

5. Pembuatan dan implementasi.

\subsubsection{Alat Bantu Analisis dan Perancangan}

Alat bantu digunakan pada analisis dan pengembangan sistem dengan tujuan untuk mempermudah dalam pengembangan suatu sistem, adapun alat bantu. Adapun alat bantu yang digunakan adalah sebagai berikut :

1. Flow Map : peta (map) yang menunjukan alir (flow) di dalam program atau prosedur sistem secara logika. Peta alir digunakan terutama untuk alat bantu komunikasi dan untuk dokumentasi. Peta alir merupakan bagian dari informasi yang menerangkan proses-proses sistem informasi tersebut.

2. Diagram Konteks : diagram yang terdiri dari suatu proses dan menggambarkan ruang lingkup suatu system. Diagram konteks merupakan level tertinggi dari DFD yang menggambarkan seluruh input ke sistem atau output dari sistem. Ia akan meberi gambaran tentang keseluruhan sistem.

3. Diagram Alir Data (Data Flow Diagram DFD) : model dari sistem untuk menggambarkan pembagian sistem ke modul yang lebih kecil.

4. Perancangan Basis Data : Pada langkah ini terdapat empat bagian, yaitu normalisasi, ERD (Entity Relationship Diagram), struktur file dan relasi tabel.

\section{HASIL PEMBAHASAN}

\subsection{Analisis Sistem Yang Berjalan}

Analisis sistem dilakukan untuk mengurai sistem yang utuh dan telah ada dengan tujuan mencari permasalahan dan kekurangan yang terjadi di sistem yang berjalan tersebut. Tujuan lain dari analisis ini yaitu untuk mengevaluasi permasalahan yang ada serta menganalisis kebutuhan sistem yang akan dibangun sehingga mampu menyelesaikan permasalahan yang ada. Berikut Gambar 2 yang menjelaskan flowmap dari sistem pendaftaran penerimaan peserta didik baru.

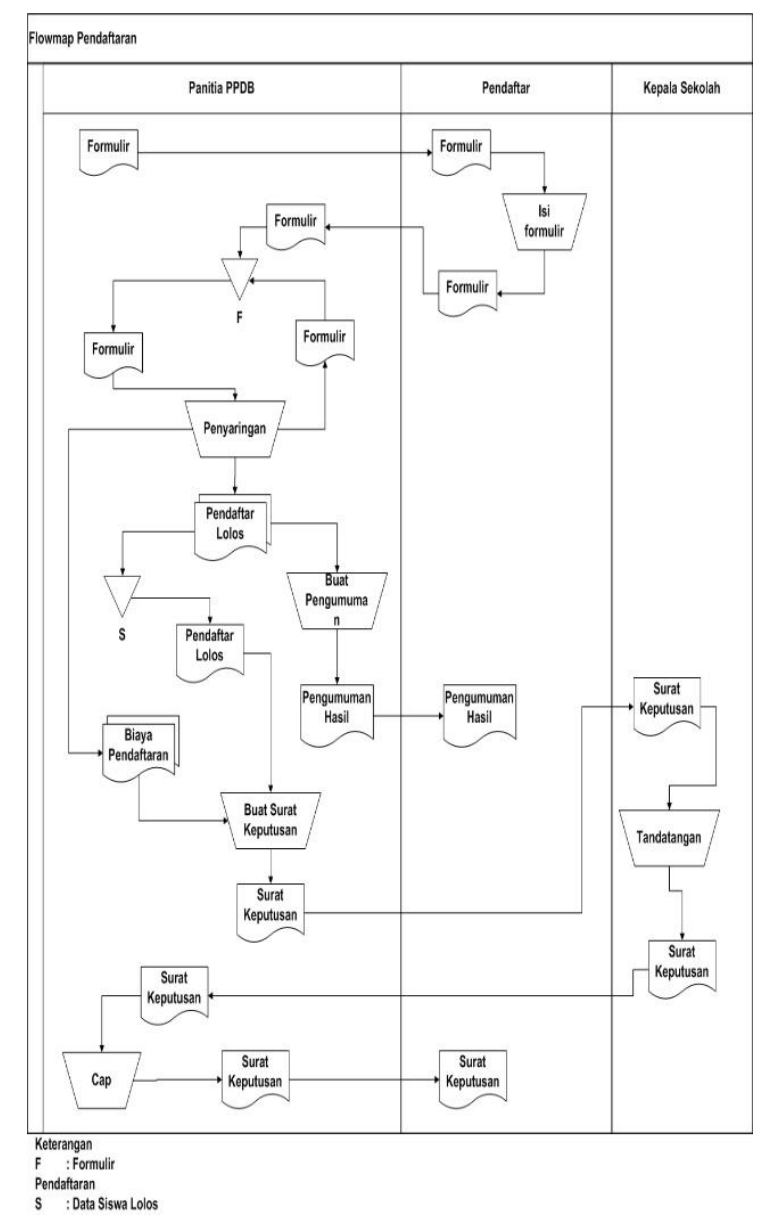

Gambar 2. Flowmap pendaftaran PPDB

Sementara untuk flowmap sistem penilaian hafiz para siswa dapat dilihat pada Gambar 3 di bawah ini 


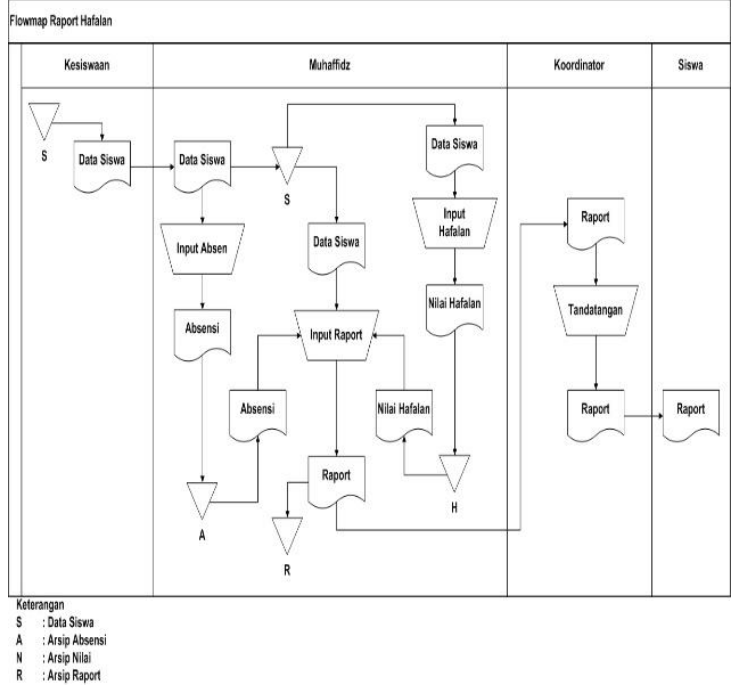

Gambar 3. Flowmap nilai hafiz siswa

\subsubsection{Diagram Konteks}

Untuk menggambarkan keterhubungan suatu sistem dibutuhkan adanya diagram konteks. Pada sistem yang berjalan saat ini dapat dilihat diagramnya pada Gambar 4 di bawah ini

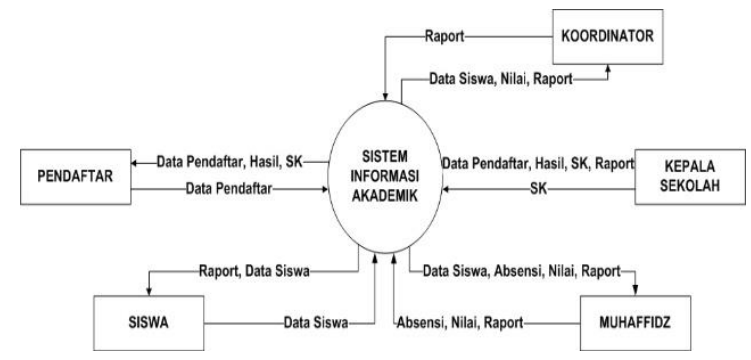

Gambar 4. Diagram konteks sistem berjalan

\subsubsection{Data Flow Diagram Level 1}

Untuk diagram aliran data level 1 dari sistem yang berjalan saat ini ditunjukkan pada gambar 5 di bawah ini.

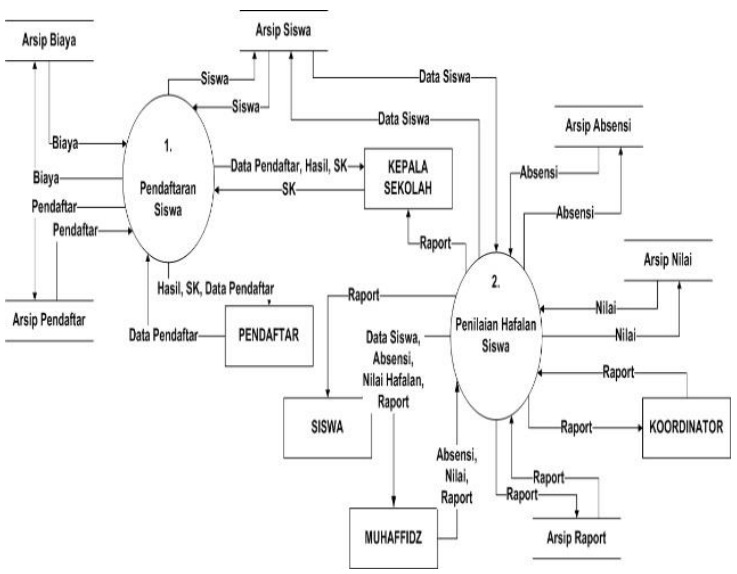

Gambar 5. DFD level 1 sistem yang berjalan

\subsubsection{Data Flow Diagram Level 2}

Di bawah ini Gambar 6 yang menunjukkan digram aliran data level 2 untuk proses pendaftaran pada sistem yang sedang berjalan.

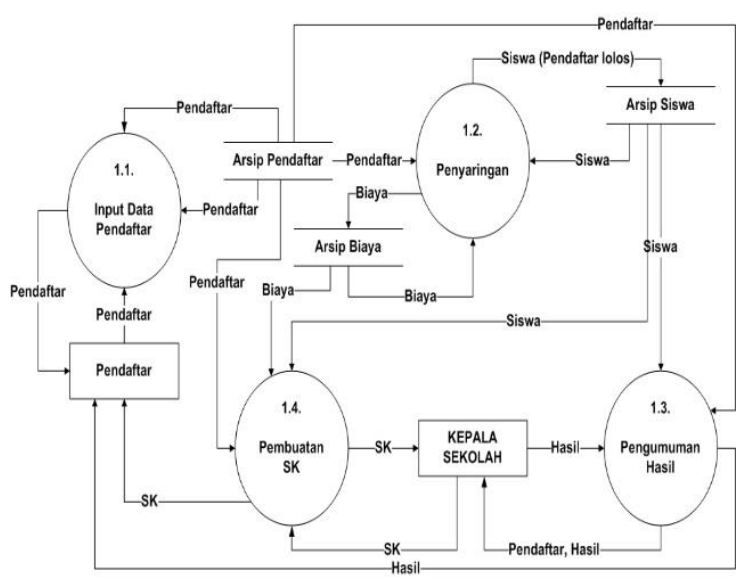

Gambar 6. DFD level 2 pendaftaran pada sistem berjalan

Untuk DFD level 2 proses penilaian hafiz harian siswa dapat dilihat pada Gambar 7 di bawah ini.

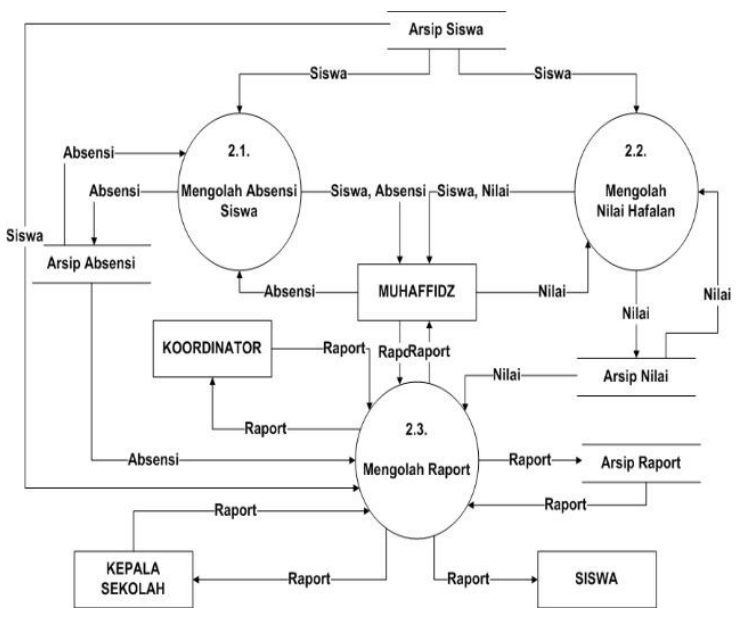

Gambar 7. DFD level 2 penilaian pada sistem berjalan

\subsection{Evaluasi Sistem Yang Berjalan}

Berdasarkan analisis aktifitas pendaftaran dan penilaian hafiz hingga rapor yang sedang berjalan saat ini, terdapat beberapa permasalahan seperti yang terlihat pada Tabel 2 di bawah ini.

Tabel 2 : Evaluasi sistem yang berjalan

\begin{tabular}{c|l|l}
\hline \hline No & \multicolumn{1}{|c|}{ Kekurangan } & \multicolumn{1}{c}{ Solusi } \\
\hline 1 & $\begin{array}{l}\text { Proses pendaftaran masih } \\
\text { manual, pendaftar harus }\end{array}$ & $\begin{array}{l}\text { Pembuatan } \\
\text { sistem informasi }\end{array}$ \\
\hline
\end{tabular}




\begin{tabular}{c|l|l}
\hline & $\begin{array}{l}\text { mengisi formulir dan } \\
\text { menyerahkan berkas } \\
\text { langsung ke panitia } \\
\text { PPDB }\end{array}$ & $\begin{array}{l}\text { pendaftaran } \\
\text { PPDB online }\end{array}$ \\
\hline 2 & $\begin{array}{l}\text { Untuk proses pencatatan } \\
\text { nilai hafiz para siswa } \\
\text { masih menggunakan } \\
\text { kertas nilai. Dan untuk } \\
\text { pengisian rapor harus } \\
\text { menyalin ulang nilai } \\
\text { harian. }\end{array}$ & $\begin{array}{l}\text { Pembuatan } \\
\text { sistem informasi } \\
\text { penilaian hafiz } \\
\text { siswa }\end{array}$ \\
\hline 3 & $\begin{array}{l}\text { Untuk pembuatan rapor, } \\
\text { absensi siswa masih } \\
\text { tercatat di buku absen. } \\
\text { Sehingga harus merekap } \\
\text { absen untuk mengisi } \\
\text { rapor. }\end{array}$ & $\begin{array}{l}\text { Pembuatan } \\
\text { sistem informasi } \\
\text { rapor siswa }\end{array}$ \\
\hline
\end{tabular}

\subsection{Perancangan Sistem}

Setelah mengevaluasi sistem yang sedang berjalan, maka diperlukan sebuah rancangan sistem informasi berbasis komputer untuk menjadi solusi dari permasalahan yang ada. Dalam merancang sistem informasi ini, diperlukan alat bantu perancangan sistem untuk memudahkan dalam proses pengembangan sistem informasi nantinya. Adapun gambaran umum dari proses-proses pada sistem informasi yang diusulkan seperti yang tertera pada Tabel 3 berikut ini.

Tabel 3 : Gambaran umum sistem informasi yang diusulkan

\begin{tabular}{c|l|l}
\hline \hline No & \multicolumn{1}{|c|}{ Proses } & \multicolumn{1}{c}{ Keterangan } \\
\hline 1 & $\begin{array}{l}\text { Manajemen } \\
\text { User }\end{array}$ & $\begin{array}{l}\text { Mengelola data user (admin, } \\
\text { pendaftar, siswa, muhafiz, } \\
\text { koordinator) yang bisa } \\
\text { mengakses sistem }\end{array}$ \\
\hline 2 & $\begin{array}{l}\text { Manajemen } \\
\text { Pendaftar }\end{array}$ & $\begin{array}{l}\text { Mengelola data pendaftar } \\
\text { beserta kelengkapan berkas }\end{array}$ \\
\hline 3 & $\begin{array}{l}\text { Manajemen } \\
\text { Hasil Seleksi }\end{array}$ & $\begin{array}{l}\text { Mengelola hasil seleksi } \\
\text { pendaftar dan total biaya tiap } \\
\text { peserta yang disertakan di } \\
\text { Surat Keputusan }\end{array}$ \\
\hline 4 & $\begin{array}{l}\text { Manajemen } \\
\text { Absensi }\end{array}$ & $\begin{array}{l}\text { Mengelola absen harian } \\
\text { siswa }\end{array}$ \\
\hline 5 & $\begin{array}{l}\text { Manajemen } \\
\text { Nilai Harian }\end{array}$ & $\begin{array}{l}\text { Mengelola nilai harian hafiz } \\
\text { para siswa }\end{array}$ \\
\hline 6 & $\begin{array}{l}\text { Manajemen } \\
\text { Nilai Rapor }\end{array}$ & $\begin{array}{l}\text { Mengelola rekap absen, nilai } \\
\text { hafiz dan hasil pencapaian } \\
\text { para siswa }\end{array}$ \\
\hline
\end{tabular}

\subsubsection{Diagram Konteks}

Diagram konteks dari sistem yang diusulkan hampir sama dengan yang berjalan, namun kepala sekolah sebagai entitas luar dimasukkan menjadi bagian dari sistem. Berikut dapat dilihat pada Gambar 8 di bawah ini.

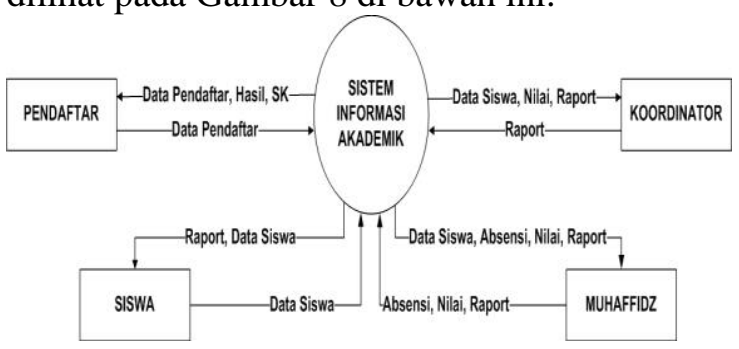

Gambar 8. Diagram konteks yang diusulkan

\subsubsection{Data Flow Diagram Level 1}

Untuk DFD yang diusulkan, terdapat proses untuk mengelompokkan siswa untuk masuk ke kelompok dan kelas mana. Selebihnya hampir sama dengan sistem yang berjalan, yaitu ada proses pendaftaran dan penilaian. Untuk lebih jelasnya dapat dilihat pada Gambar 9 di bawah ini.

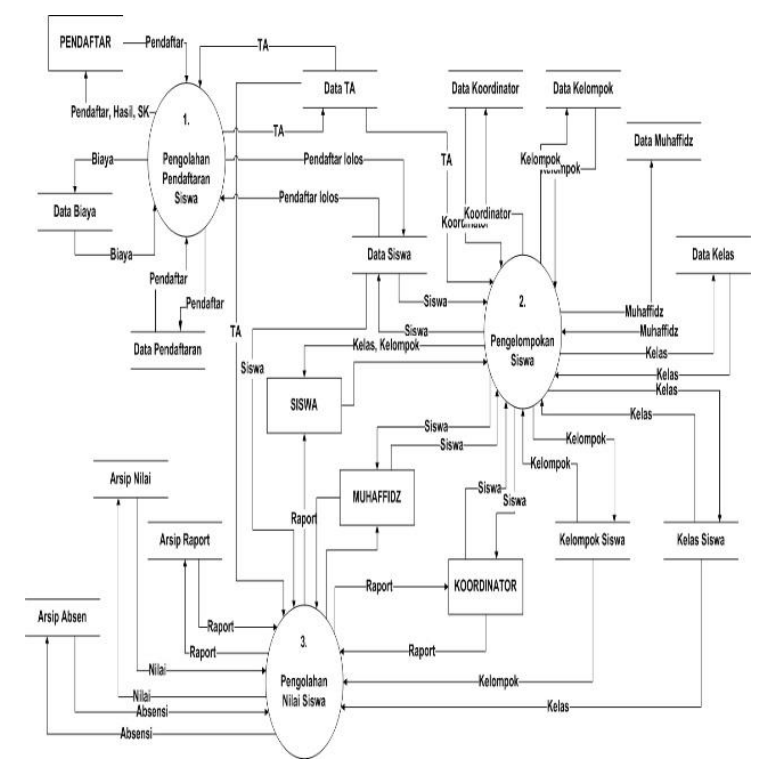

Gambar 9. DFD level 1 yang diusulkan

\subsubsection{Data Flow Diagram Level 2}

Untuk DFD level 2 proses pendaftaran diusulkan secara garis besar sama dengan yang berjalan, dapat dilihat pada Gambar 10 di bawah ini. 


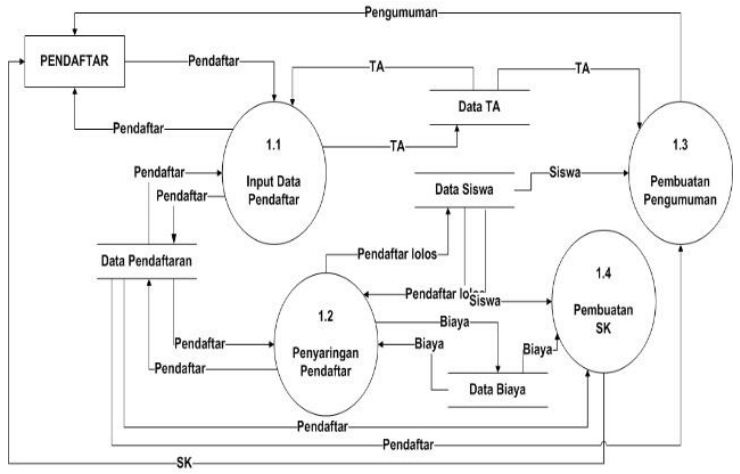

Gambar 10. DFD level 2 yang diusulkan untuk proses pendaftaran

Untuk DFD level 2 proses pengelompokkan siswa dapat dilihat secara jelas pada Gambar 11 di bawah ini

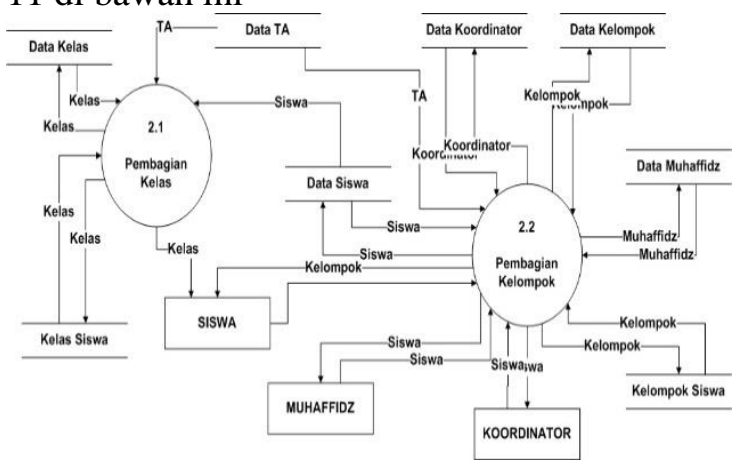

Gambar 11. DFD level 2 yang diusulkan untuk proses pengelompokkan siswa

Yang terakhir, DFD level 2 untuk proses penilaian dan rapor siswa yang diusulkan dapat dilihat pada Gambar 12 di bawah ini

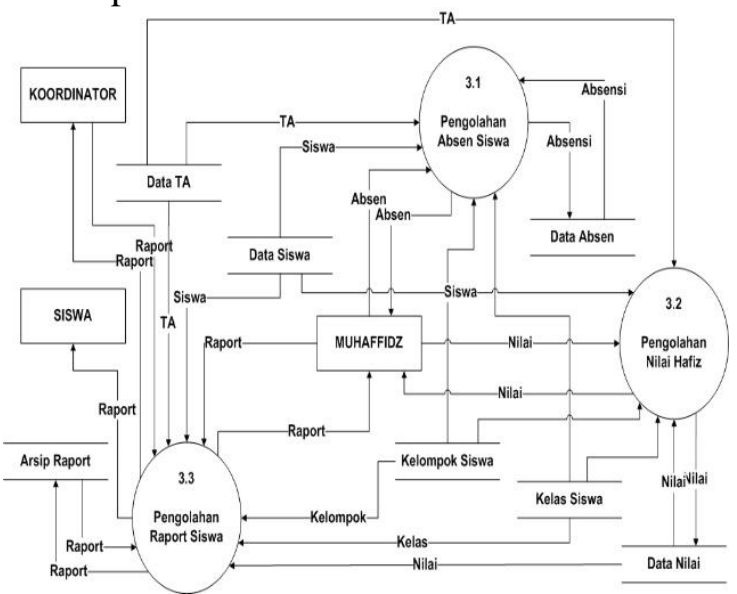

Gambar 12. DFD level 2 yang diusulkan untuk proses pengolahan nilai siswa

\subsection{Implementasi Sistem}

Setelah proses analisis dan perancangan sistem, maka selanjutnya adalah proses implementasi sistem. Terdapat beberapa modul yang digunakan pada implementasi sistem yang diusulkan.

\subsubsection{Manajemen User}

Untuk mengelola user pendaftar, admin cukup membuat user baru untuk laki-laki atau perempuan yang passwordnya dibuat secara random. Berikut di bawah ini Gambar 13 yang menujukkan halaman manajemen user pendaftar.

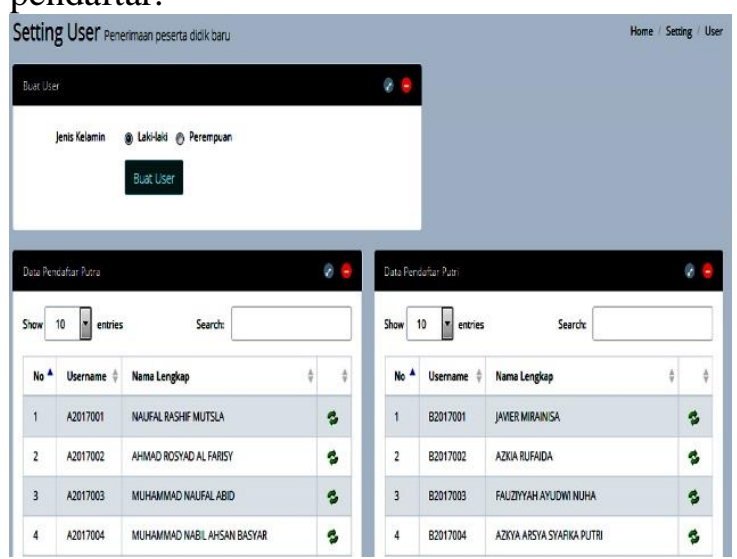

Gambar 13. Manajemen user pendaftar

Sementara untuk user muhafiz, halaman manajemen usernya dapat dilihat pada Gambar 14 di bawah ini

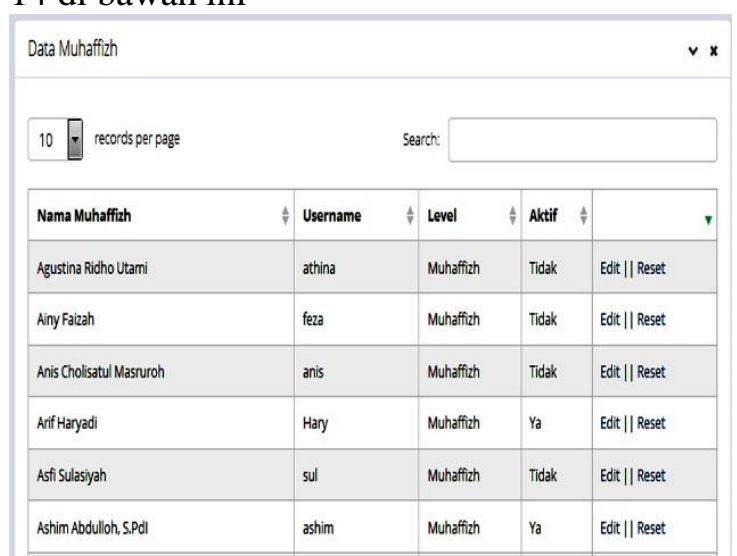

Gambar 14. Manajemen user muhafiz

\subsubsection{Manajemen Pendaftar}

Untuk data pendaftar, user hanya dapat melihat list para pendaftar namun admin dapat memproses edit, hapus, export data, export kuisioner dan melihat formulir pendaftar. Untuk lebih jelasnya dapat dilihat pada Gambar 15 di bawah ini. 


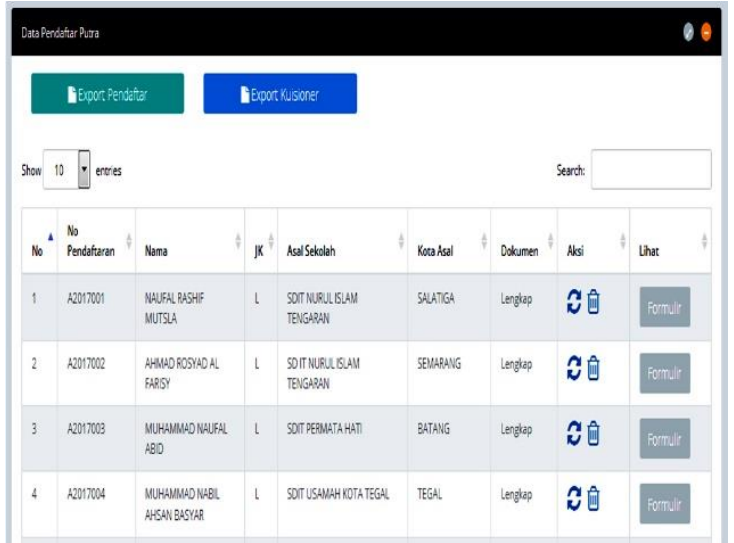

Gambar 15. Manajemen pendaftar

\subsubsection{Manajemen Hasil Seleksi}

Hasil seleksi para pendaftar dikelola oleh admin dengan cara mengimport dari file .xls. pendaftar hanya bisa melihat hasil milik sendiri berupa surat keputusan. Berikut di bawah ini Gambar 16 untuk tampilan manajemen hasil seleksi

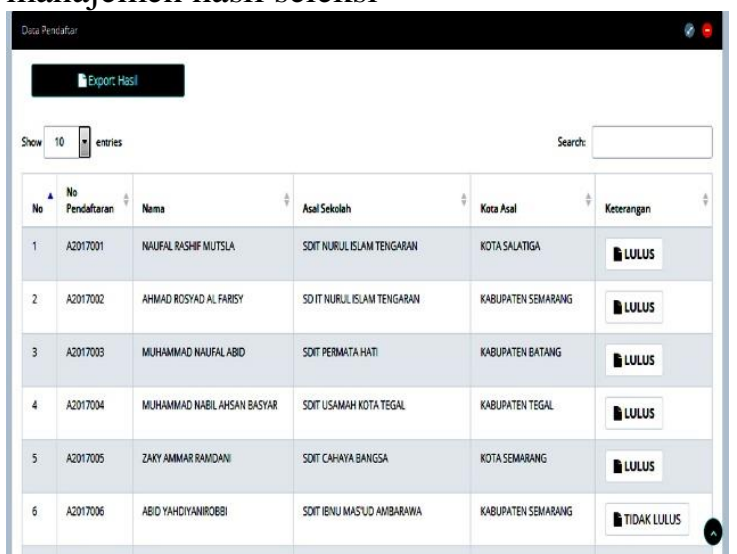

Gambar 16. Manajemen hasil seleksi

Untuk hasil seleksi berupa surat keputusan dapat diihat pada Gambar 17 berikut

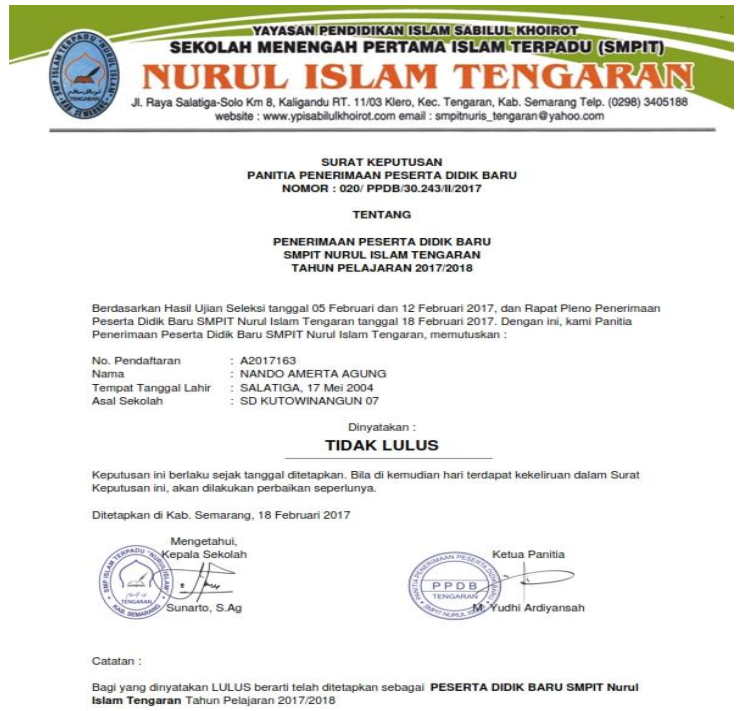

Gambar 17. Surat keputusan

\subsubsection{Manajemen Absensi}

Muhafiz dapat menginput dan merubah absen harian siswa, dan hasil absensi harian per bulannya dapat dilihat pada Gambar 18 di bawah ini.

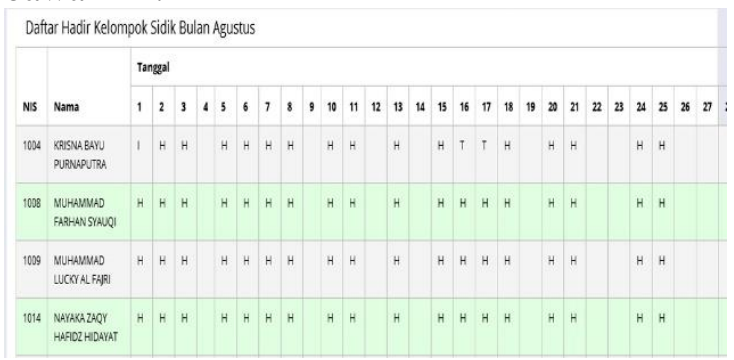

Gambar 18. Manajemen absensi

\subsubsection{Manajemen Nilai Harian}

Selain input absensi harian, muhafiz juga menginput nilai siswa setiap tes hafalan. Dalam satu hari bisa lebih dari satu poin. Atau bahkan satu poin dalam beberapa hari. Sistem yang dirancang memungkinkan muhafiz menginput dan merubah nilai beserta tanggal tes hafalan siswa. Berikut di bawah ini Gambar 19 yang menjelaskan manajemen nilai harian 


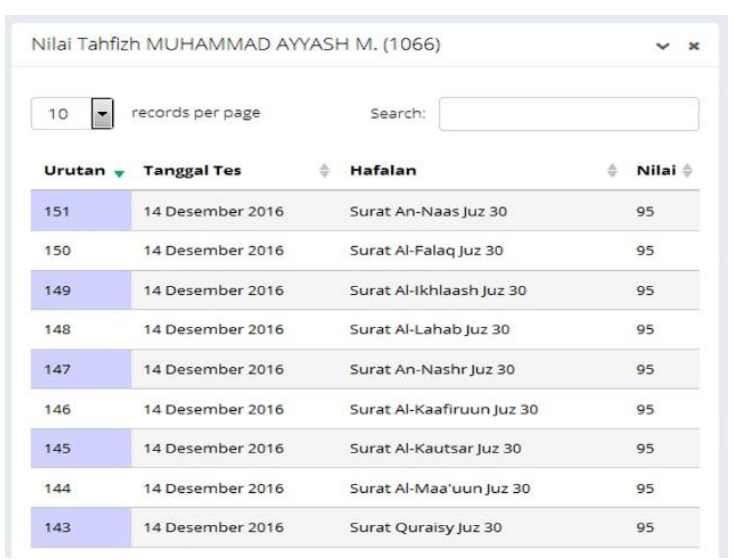

Gambar 19. Manajemen nilai harian

\subsubsection{Manajemen Nilai Rapor}

Yang terakhir adalah manajemen rapor. Pada halaman ini, muhafiz mengisikan catatan untuk siswa yang akan dicetak pada rapor. Untuk rekap absen dan nilai hafalan siswa secara otomatis ditampilkan berdasarkan nama siswa.

\section{KESIMPULAN}

\subsection{Kesimpulan}

Melihat hasil penelitian yang sudah dilakukan, dapat ditarik kesimpulan berupa :

1. Dengan adanya sistem informasi akademik (SIAK) di SMPIT Nurul Islam Tengaran maka dapat membantu kegiatan pendaftaran PPDB yang tadinya dilaksanakan secara manual menjadi online, sehingga dapat menjadi lebih mudah dan meminimalisir resiko terjadinya kesalahan.

2. Rekap absensi dan nilai hafalan siswa secara otomatis sangat membantu muhafiz pada saat pembuatan rapor siswa.

\subsection{Saran}

Untuk semakin meningkatnya kinerja dari SIAK SMPIT Nurul Islam Tengaran, maka untuk kedepannya diperlukan pengembangan lebih lanjut. Adapun saran terkait SIAK selanjutnya, sebaiknya diintegrasikan dengan sistem yang sudah ada di SMPIT Nurul Islam Tengaran.

\section{DAFTAR PUSTAKA}

[1] Azhar Susanto, Sistem Informasi Akuntansi. Bandung: Lingga Jaya, 2013.

[2] Mohamad Subhan, Analisa Perancangan Sistem. Jakarta: Lentera Ilmu Cendikia,
2012.

[3] Rudy Tantra, Manajemen Proyek Sistem Informasi. Yogyakarta: Andi, 2012.

[4] Abdul Kadir, Pengenalan Sistem Informasi Edisi Revisi. Yogyakarta: Andi.

[5] KBBI. (2017, Mei) Kamus Besar Bahasa Indonesia. [Online]. HYPERLINK "http://kbbi.web.id/" http://kbbi.web.id/

[6] Tata Sutabri, Analisis Sistem Informasi. Yogyakarta: Andi, 2012.

[7] Pipin Asropudin, Kamus Teknologi Informasi Komunikasi. Bandung: Titian Ilmu, 2013.

[8] Julian Chandra Wibawa and Muhammad Rajab Fachrizal, "Pengembangan Sistem Informasi Penjadwalan ". 